\title{
Influence of Subcutaneous Fat Layer in Skin Temperature
}

\author{
Influência da Camada de Gordura Subcutânea na Temperatura da Pele
}

\author{
Eduardo Borba Neves ${ }^{1,3^{*}}$, José Vilaça-Alves ${ }^{2,3}$, Isabel Regina Amorim Nogueira3 ${ }^{3}$ Victor \\ Machado Reis 2,3
}

ORIGINAL ARTICLE | ARTIGO ORIGINAL \begin{abstract}
The aim of this study was to determine the correlation between the subcutaneous fat layer and the temperature variation (core - skin) in two body regions, measured by infrared sensors. This study involved 43 volunteers selected among undergraduate students in physical education. The thermal images and skinfold thickness were acquired from subscapular region (SB) for male and triceps region (TR) for female volunteers, of right side. In this study, subscapular skinfold thickness was inversely correlated with skin temperature $(\mathrm{r}=-0.638, \mathrm{p}=0.004)$ and directly correlated with $\Delta \mathrm{T}$ [core - skin] $(\mathrm{r}=0.653, \mathrm{p}=0.003)$. However, the results for the triceps region showed no significant correlation between triceps skinfold thickness and skin temperature or $\Delta \mathrm{T}$ [core - skin]. When the sample was separated into two groups by skinfold thickness, with cut off at $12 \mathrm{~mm}$, average comparison tests for $\Delta \mathrm{T}$ [core - skin] shows statistically significant difference between groups for the subscapular site (Student t test for independent sample, $p$ value $=0.023$ ), but not for the triceps site (Wilcoxon Signed Ranks and the Mann-Whitney tests, $p$ value $=0.268$ ). In short, the findings suggest that subcutaneous fat layer correlates negatively with skin temperature in subscapular region.

Keywords: thermography; subcutaneous fat layer; skin temperature; human thermal physiology; skinfold thickness.
\end{abstract}

RESUMO

O objetivo deste estudo foi determinar a correlação entre a camada de gordura subcutânea e a variação de temperatura (core - pele) em duas regiões do corpo, medida por sensores infravermelhos. Este estudo envolveu 43 voluntários, selecionados entre os estudantes de graduação em educação física. As imagens térmicas e dobras cutâneas foram adquiridas da região subescapular (SB) para o sexo masculino e da região tricipital (TR) para as voluntárias do sexo feminino, ambas do lado direito do corpo. Neste estudo, a espessura da prega cutânea subescapular, correlacionou-se inversamente com a temperatura da pele $(\mathrm{r}=$ $0,638, \mathrm{p}=0,004)$ e positivamente com a variação de temperatura [central - pele] $(\mathrm{r}=0,653, \mathrm{p}=0,003)$. No entanto, os resultados para a região tricipital não mostrou correlação significativa com a temperatura da pele ou com a variação de temperatura [central - pele]. Quando a amostra foi separada em dois grupos, pela espessura da prega cutânea, com ponto de corte em $12 \mathrm{~mm}$, teste de médias de comparação para a variação de temperatura [central - pele] mostrou diferença estatisticamente significativa entre os grupos para a região subescapular (teste t de Student para amostra independente, valor de $\mathrm{p}=0,023$ ), mas não para a região tricipital (Wilcoxon Signed Ranks e os testes de Mann-Whitney, $p=0,268$ ). Em suma, os resultados sugerem que a camada subcutânea de gordura está negativamente correlacionada com a temperatura da pele na região subescapular.

Palavras-chave: termografia; camada de gordura subcutânea; temperatura da pele; fisiologia humana térmica; dobras cutâneas.

\footnotetext{
Manuscript received at October $16^{\text {th }} 2014$; Accepted at June $10^{\text {th }} 2015$

${ }^{1}$ Brazilian Army Research Institute of Physical Fitness, Rio de Janeiro, Brazil

${ }^{2}$ Research Centre in Sports Sciences, Health Sciences and Human Development, CIDESD, Portugal

${ }^{3}$ University of Trás-os-Montes and Alto Douro, Vila Real, Portugal

* Autor correspondente: Eduardo Borba Neves, Av João Luis Alves s/nº Fortaleza de São João - Urca, Rio de Janeiro, RJ, Brazil. E-mail: borbaneves@hotmail.com
} 


\section{INTRODUCTION}

The human body has complex mechanisms responsible for the control of body temperature involving thermal sensors such as the hypothalamus and efferent systems. The constant core body temperature is essential to sustain homeostasis and maintaining the functions and composition of tissues and fluids (Jones \& Plassmann, 2002). Thermography is recognized diagnostic method since the 1980s by the American Medical Association. This method involves the detection of infrared radiation emitted by the skin noninvasively without exposing the patient to radiation of any kind (Neves \& Reis, 2014).

Heat dissipation is influenced by many variables. Among them, the local vascularization and subcutaneous fat layer (Bandeira, Moura, Souza, Nohama, \& Neves, 2012), that is different in male and female subjects (Jones \& Plassmann, 2002).

Chudecka and Lubkowska (2012) found a strong correlation between maximal oxygen consumption and a decrease in surface temperature of the upper limbs, immediately after the physical training of a volleyball team. With these findings, the authors suggest that thermography can be used as an additional, noninvasive method to assess the fitness level of the athletes. They further report that the best place for such evaluation is the front surface of the arms and forearms, because the back side has a greater subcutaneous fat layer, which may act as an insulator of heat generated by the body.

Other authors (Bandeira et al., 2012; Jones \& Plassmann, 2002) have also reported the influence of subcutaneous fat layer in the assessments thermal images. However, they not deepened the discussion of the magnitude and direction of this influence. Furthermore, it is known that the skin temperature depends on the core temperature (Havenith, Smith, \& Fukazawa, 2008), so it is important to consider core temperature in analysis of fat layer influence for skin temperature when measured by infrared sensors.

Elucidation of these relationships can contribute to the knowledge about the human thermal physiology and can be applied immediately in the sports training planning (Neves \& Reis, 2014) and in development of products such as sporting clothing (Bogerd, Psikuta, Daanen, \& Rossi, 2010). In this sense, the aim of this study was to determine the correlation between the subcutaneous fat layer and the temperature variation (core - skin) in two body regions, measured by infrared sensors.

\section{MATERIAL AND METHODS \\ Participants}

This study involved 43 volunteers (18 males and 25 females) selected among graduate students in physical education and the research protocol was approved by Human Research Ethics Committee of Campos de Andrade University Center under CAAE number 28901414.3.0000.5218.

The inclusion criterion for participation in the study was to present tympanic temperature (regarded as core temperature) ranging between 36.0 and 36.5 in order to keep the homogeneity of the sample (with a slight variation in core temperature).

\section{Instrumentation and Data Acquisition}

It was used a thermographic camera (FLIR Systems Inc. Model SC2000); a computer (with specific software for acquisition and processing of thermographic images ThermaCam ${ }^{\mathrm{TM}}$ Researcher Pro 2.9); and a term digital hygrometer to monitor the temperature and humidity of the room. The thermographic camera used has a resolution of $320 \times 240$ pixels, which has sensors that measures temperatures ranging from $-20^{\circ} \mathrm{C}$ to $+120^{\circ} \mathrm{C}$. This camera has a sensitivity to detect differences of less than $0.1^{\circ} \mathrm{C}$ temperature and provides accuracy of $\pm 1^{\circ} \mathrm{C}$ of the absolute temperature.

The first part of thermal images acquisition protocol was the region of interest (ROI) delineation using tape (which reduces the emission of infrared radiation where the ribbon is attached and allows recognizing the markers in the thermal image) (Neves \& Reis, 2014). Next, the volunteers remained for 15 minutes 
in an acclimatized room with temperature of $23^{\circ} \mathrm{C}$ for reaching thermal balance before the images acquisition (Bandeira et al., 2014).

The thermal images were acquired from subscapular region (SB) for male and triceps region (TR) for female volunteers, of right side, at the site of measurement of skinfold thickness, as the protocol described by (Neves, Ripka, Ulbricht, \& Stadnik, 2013). The skinfolds thicknesses of these sites were assessed according to Gonçalves and Mourão (2008).

It was also used the following equipment for the anthropometric assessment: one digital scale (Wiso W801), with capacity of $0-180 \mathrm{~kg}$ and grading of $100 \mathrm{~g}$; one calibrated scientific adipometer (Cescorf); and one stadiometer (WCS Woody Compact).

The skinfold thickness used was selected because the subscapular and the triceps site have, normally, a large subcutaneous fat layer in man (Neves et al., 2013; Ross et al., 1994) and women (Ross et al., 1994)), respectively.

The core temperature (Tc) was measured by tympanic access using a Braun Thermoscan infrared ear tympanic thermometer, because as the eardrum shares the same arterial blood supply to the hypothalamus, the tympanic temperature may be considered as the Tc (Potter \& Perry, 2006).

The values of temperature variation (core skin) were calculated according to Equation 1.

$$
\Delta T=T c-T s k
$$

Where: $\Delta \mathrm{T}=$ temperature variation $\left({ }^{\circ} \mathrm{C}\right), \mathrm{Tc}$ $=$ core temperature $\left({ }^{\circ} \mathrm{C}\right), \quad$ Tsk $=$ skin temperature $\left({ }^{\circ} \mathrm{C}\right)$.

\section{Data Processing and Analysis}

All acquired image were analyzed by FLIR ThermaCam $^{\mathrm{TM}}$ Researcher Pro 2.9 software. The software was set to treat the image in the colour palette midgreen (Sanches, Gamba, Souza, Neves, \& Nohama, 2013) with background temperature of $22^{\circ} \mathrm{C}$ and emissivity of 0.98 (Neves \& Reis, 2014). The circle tool was used and the average temperature of ROI in subscapular and triceps regions was considered, as illustrated in Figures 1 and 2.

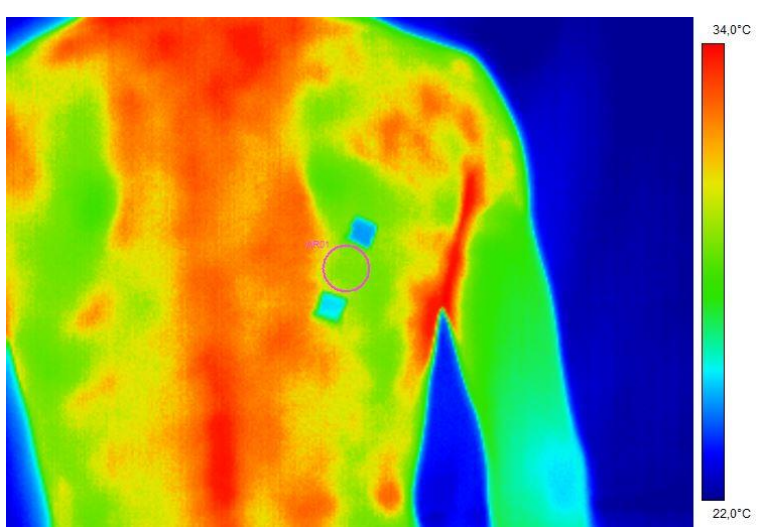

Figure 1. Illustration of thermal images analysis (subscapular region).

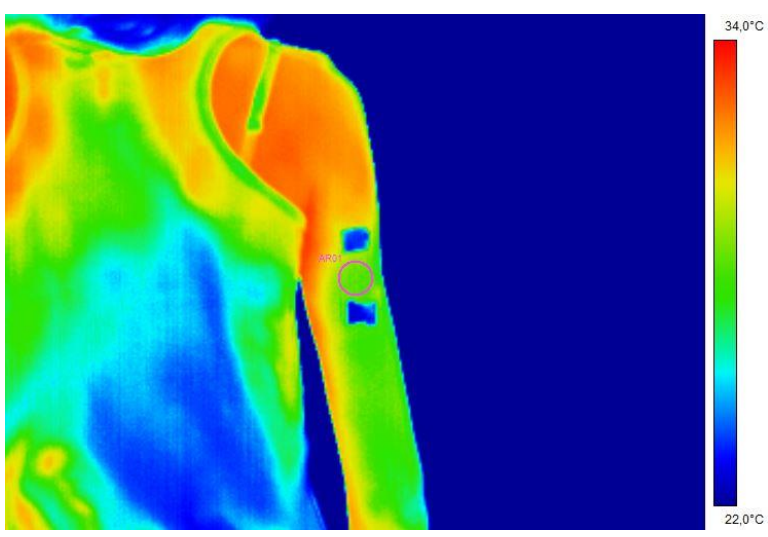

Figure 2. Illustration of thermal images analysis (triceps region).

The Statistical analyses were performed with Statistical Package for Social Sciences (SPSS, version 21.0). Descriptive statistics (means and SD) were used to summarize the characteristics of the study sample, ShapiroWilk test was performed to test the variable distributions, Pearson (r) and Spearman (rho) correlation analysis was used for the main evaluations; the Student $\mathrm{t}$ test, Wilcoxon Signed Ranks and the Mann-Whitney tests were applied to verify the difference between groups. The statistical significance level was defined as $\mathrm{p}<0.05$.

\section{RESULTS}

The main characteristics of study sample was presented in Tables 1 and 2 . 
Table 1:

Average and standard deviation of male sample, Vila Real, Portugal, 2014.

\begin{tabular}{lcccc}
\hline \multicolumn{1}{c}{ Variables } & $\mathrm{N}$ & Median & Avg & SD \\
\hline Age (years) & 18 & 21.00 & 21.39 & 1.54 \\
Tympanic temperature $\left({ }^{\circ} \mathrm{C}\right)$ & 18 & 36.13 & 36.16 & 0.01 \\
Weight $(\mathrm{Kg})$ & 18 & 73.20 & 89.48 & 38.97 \\
Height $(\mathrm{cm})$ & 18 & 175.85 & 161.60 & 40.16 \\
SB skinfold thickness $(\mathrm{mm})$ & 18 & 9.17 & 9.33 & 3.42 \\
SB skin temperature $\left({ }^{\circ} \mathrm{C}\right)$ & 18 & 31.6 & 31.36 & 0.99 \\
$\Delta$ T core - skin $\left({ }^{\circ} \mathrm{C}\right)$ & 18 & 4.65 & 4.79 & 0.96 \\
\hline
\end{tabular}

Legend: Avg = average, $\mathrm{SD}=$ standard deviation, $\mathrm{SB}=$ subscapular, $\Delta \mathrm{T}=$ temperature difference (variation).

Table 2:

Average and standard deviation of female sample, Vila Real, Portugal, 2014.

\begin{tabular}{lcccc}
\hline \multicolumn{1}{c}{ Variables } & $\mathrm{N}$ & Median & Avg & SD \\
\hline Age $($ years $)$ & 25 & 20.00 & 20.50 & 1.75 \\
Tympanic temperature $\left({ }^{\circ} \mathrm{C}\right)$ & 25 & 36.25 & 36.25 & 0.17 \\
Weight $(\mathrm{Kg})$ & 25 & 57.90 & 57.57 & 7.62 \\
Height $(\mathrm{cm})$ & 25 & 163.00 & 161.85 & 5.20 \\
TR skinfold thickness $(\mathrm{mm})$ & 25 & 14.43 & 14.77 & 5.61 \\
TR skin temperature $\left({ }^{\circ} \mathrm{C}\right)$ & 25 & 29.30 & 29.43 & 0.90 \\
$\Delta$ T core - skin $\left({ }^{\circ} \mathrm{C}\right)$ & 25 & 6.95 & 6.83 & 0.94 \\
\hline
\end{tabular}

Legend: Avg = average, $\mathrm{SD}=$ standard deviation, $\mathrm{TR}=$ triceps, $\Delta \mathrm{T}$ = temperature difference (variation).

The results of Shapiro-Wilk test showed $p=$ 0.033 for $\Delta \mathrm{T}$ core - skin $\left({ }^{\circ} \mathrm{C}\right)$ acquired at triceps. All others variables presented $\mathrm{p}$ value high than 0.05. Thus, was carry out the Spearman correlation between $\Delta \mathrm{T}$ core - skin $\left({ }^{\circ} \mathrm{C}\right)$ and triceps skinfold thickness, and Pearson correlation between $\Delta \mathrm{T}$ core - skin $\left({ }^{\circ} \mathrm{C}\right)$ and triceps skinfold thickness. All results of correlations tests was showed in Table 3.

Table 3:

Results of correlations among the variables: skin temperature, $\Delta T$ core - skin $\left({ }^{\circ} \mathrm{C}\right)$ and skinfold thickness in considered site, Vila Real, Portugal, 2014.

\begin{tabular}{cccc}
\hline Anatomical Site & & Skin temperature & $\Delta \mathrm{T}$ core - skin $\left({ }^{\circ} \mathrm{C}\right)$ \\
\hline Skinfold Thickness & Pearson $(\mathrm{r})$ & -0.638 & 0.653 \\
Subscapular & $p$ value & 0.004 & 0.003 \\
& $\mathrm{~N}$ & 18 & 18 \\
\hline \multirow{2}{*}{ Skinfold Thickness } & Spearman (rho) & 0.220 & -0.240 \\
Triceps & $p$ value & 0.290 & 0.247 \\
& $\mathrm{~N}$ & 25 & 25 \\
\hline
\end{tabular}

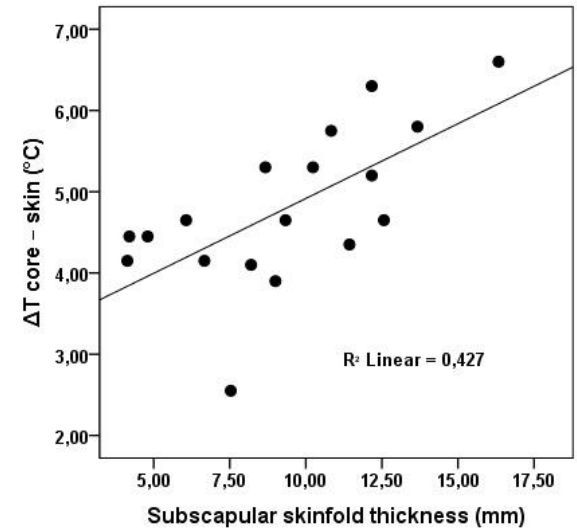

Figure 3. Scatter plot of relationship between subscapular skinfold thickness $(\mathrm{mm})$ and $\Delta$ Temperature [core - skin] $\left({ }^{\circ} \mathrm{C}\right)$.

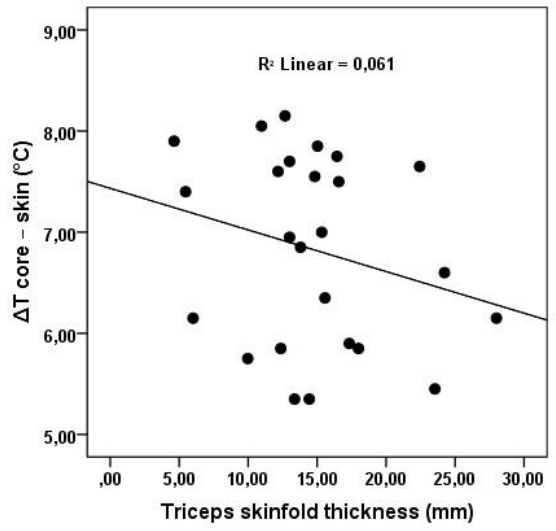

Figure 4. Scatter plot of relationship between triceps skinfold thickness $(\mathrm{mm})$ and $\Delta$ Temperature [core - skin] $\left({ }^{\circ} \mathrm{C}\right)$. 
Figures 3 and 4 show the scatter plot of the $\Delta \mathrm{T}$ [core - skin] $\left({ }^{\circ} \mathrm{C}\right)$ and skinfold thickness in each of the anatomical sites studied.

When the sample was separated into two groups by skinfold thickness, with cut off at $12 \mathrm{~mm}$, average comparison tests for $\Delta \mathrm{T}$ [core skin] shows statistically significant difference between groups for the subscapular site (Student $\mathrm{t}$ test for independent sample, $p$ value $=0.023$ ), but not for the triceps site (Wilcoxon Signed Ranks and the Mann-Whitney tests, $p$ value $=0.268)$.

\section{DISCUSSION}

McArdle, Katch, and Katch (2011) and Guyton and Hall (2011) report that fat acts as a good insulator because it has a low thermal conductivity. This study aimed to determine the correlation between the subcutaneous fat layer and the temperature variation $(\Delta \mathrm{T}$ [core skin]) in two body regions, measured by infrared sensors. The sample can be considered thermally homogeneous within groups of males (subscapular thickness) and female (triceps thickness) because shown a small standard deviation in tympanic and skin temperature.

Although the studied groups present gender difference, the results suggest that the subscapular region has a higher skin temperature than triceps region. One explanation for this may be linked to physiological maintenance processes of life, such as the heartbeat and breathing, which provide continuous heat generation and a large blood flow in the region subscapular (Netter, 2010; Neves \& Reis, 2014; Pocock, Richards, \& Richards, 2013), on the other hand, in the triceps region, at rest situation, heat is originated primarily from the blood flow, which is smaller than that of subscapular region (Netter, 2010; Pocock et al., 2013).

In this study, subscapular skinfold thickness was inversely correlated with skin temperature $(\mathrm{r}=-0.638, \mathrm{p}=0.004)$ and directly correlated with $\Delta \mathrm{T}$ [core - skin] $(\mathrm{r}=0.653, \mathrm{p}=0.003)$. Bandeira, Moura, Souza, Nohama, and Neves (2012) published similar results when reported has found significant correlation between thigh skin temperature and thigh skinfold thickness $(\mathrm{r}=-0.488, \mathrm{p}=0.020)$ over rectus femoris muscle, in volunteers with a thigh skinfold thickness mean of 11.40. In the same sense, Savastano et al. (2009) compared skin temperature in the abdominal region into two groups (obese and normal weight) and noted that the abdominal skin temperature of obese group was lower than in normal-weight group, even with no difference between groups for core temperature. The correlation (r) between abdominal skin temperature and body fat percentage founded by Savastano et al. (2009) was 0.545 . The same authors suggest that regions of the body of greater adiposity reduce the dissipation of central heat and the peripheral areas such as upper limbs can exercise greater heat dissipation.

However, the results of this study also showed no significant correlation between triceps skinfold thickness and skin temperature or $\Delta \mathrm{T}$ [core - skin]. And, observing the analysis of groups when stratified into two subgroups (larger skinfolds and smaller than $12 \mathrm{~mm}$ ), it is noticed that there is statistically difference between the subgroups of subscapular region, but the same does not happen in the triceps region. This fact maybe can explained because the women show biceps skinfold thickness with coefficients of variation greater than those found in other places of skinfold thickness assessment (Amaral et al., 2011; Kannieappan, Deussen, Grivell, Yelland, \& Dodd, 2013). This can also lead to changes in places of greater heat dissipation of arm (Savastano et al., 2009).

Regarding the study limitations, it can be pointed the missing of measurement of muscle mass under the ROIs studied, since the muscle mass can influence the skin temperature (Neves, Bandeira, Ulbricht, Vilaça-Alves, \& Reis, 2015). These findings just can be generalized to men's trunk region and to women's triceps region, in subjects with similar range of skinfold thickness. Others studies are necessary to widen the knowledge about the influence of subcutaneous fat layer in whole body. 


\section{CONCLUSIONS}

In short, the findings suggest that subcutaneous fat layer correlates negatively with skin temperature in subscapular region and, considering anatomical characteristics, this result may be generalizable to other regions of the trunk. No significant correlations between the skin temperature and subcutaneous fat layer for triceps region were observed. These results suggest that the variability of the subcutaneous fat layer distribution can change the regions of heat dissipation. Future studies must to consider the inclusion of subcutaneous fat layer as a covariable in the statistical analysis, since it influences the skin temperature acquired by infrared sensors.

\section{Acknowledgments:}

We would like to thank Brazilian Army and CNPq by the scholarship to Eduardo Borba Neves.

\section{Conflicts of Interest:}

Nothing to declare.

\section{Funding:}

Bolsa CNPq - Program Ciência sem Fronteiras Processo n. ${ }^{\circ}$ 202481/2014-0 - PDE

\section{REFERENCES}

Amaral, T. F., Restivo, M. T., Guerra, R. S., Marques, E., Chousal, M. F., \& Mota, J. (2011). Accuracy of a digital skinfold system for measuring skinfold thickness and estimating body fat. The British Journal of Nutrition, 105(3), 478-484. http://doi.org/10.1017/S0007114510003727

Bandeira, F., Moura, M. A. M. de, Souza, M. A. de, Nohama, P., \& Neves, E. B. (2012). Can thermography aid in the diagnosis of muscle injuries in soccer athletes? Revista Brasileira de Medicina Do Esporte, 18(4), 246-251. http://doi.org/10.1590/S151786922012000400006

Bandeira, F., Neves, E. B., Moura, M. A. M. de, Nohama, P., Bandeira, F., Neves, E. B., ... Nohama, P. (2014). The thermography in support for diagnosis of muscle injury in sport. Revista Brasileira de Medicina Do Esporte, 20(1), 59-64. http://doi.org/10.1590/S151786922014000100012
Bogerd, N., Psikuta, A., Daanen, H. a. M., \& Rossi, R. M. (2010). How to measure thermal effects of personal cooling systems: human, thermal manikin and human simulator study. Physiological Measurement, 31(9), 1161-1168. http://doi.org/10.1088/0967-3334/31/9/007

Chudecka, M., \& Lubkowska, A. (2012). The Use of Thermal Imaging to Evaluate Body Temperature Changes of Athletes During Training and a Study on the Impact of Physiological and Morphological Factors on Skin Temperature. Human Movement, 13(1), 33-39. http://doi.org/10.2478/v10038-0120002-9

Gonçalves, F., \& Mourão, P. (2008). A Avaliação da Composição Corporal: A Medição de Pregas Adiposas como Técnica para a Avaliação da Composição Corporal. Motricidade, 4(4), 1321. http://doi.org/10.6063/motricidade.4(4).255

Guyton, A., \& Hall, J. (2011). Tratado de Fisiologia Médica (12th ed.). Rio de Janeiro: Elsevier.

Havenith, G., Smith, C., \& Fukazawa, T. (2008). The skin interface - meeting point of physiology and clothing science. Journal of Fiber Bioengineering and Informatics, 1(2), 93-98. http://doi.org/10.3993/jfbi09200802

Jones, B. F., \& Plassmann, P. (2002). Digital infrared thermal imaging of human skin. IEEE Engineering in Medicine and Biology Magazine, 21(6), 41-48. http://doi.org/10.1109/MEMB.2002.1175137

Kannieappan, L. M., Deussen, A. R., Grivell, R. M., Yelland, L., \& Dodd, J. M. (2013). Developing a tool for obtaining maternal skinfold thickness measurements and assessing inter-observer variability among pregnant women who are overweight and obese. BMC Pregnancy and Childbirth, 13, 42. http://doi.org/10.1186/1471-2393-13-42

McArdle, W. D., Katch, F. I., \& Katch, V. L. (2011). Fisiologia do exercício: nutrição, energia e desempenho humano. Rio de Janeiro: Guanabara Koogan.

Netter, F. H. (2010). Atlas of Human Anatomy. Philadelphia: Elsevier Health Sciences.

Neves, E. B., Bandeira, F., Ulbricht, L., Vilaça-Alves, J., \& Reis, V. M. (2015). Influence of Muscle Cross-sectional Area in Skin Temperature: In Proceedings of the International Conference on Bioimaging (pp. 64-68). Lisboa: SCITEPRESS Science and and Technology Publications. http://doi.org/10.5220/0005181500640068

Neves, E. B., \& Reis, V. M. (2014). Fundamentos da termografia para o acompanhamento do treinamento desportivo. Revista UNIANDRADE, 15(2), 79-86. http://doi.org/10.18024/15195694/revuniandrade.v15n2p79-86

Neves, E. B., Ripka, W. L., Ulbricht, L., \& Stadnik, A. M. W. (2013). Comparison of the fat percentage obtained by bioimpedance, 
ultrasound and skinfolds in young adults. Revista Brasileira de Medicina Do Esporte, 19(5), 323-327. http://doi.org/10.1590/S151786922013000500004

Pocock, G., Richards, C. D., \& Richards, D. (2013). Human Physiology. Oxford: Oxford University Press.

Potter, P. A., \& Perry, A. G. (2006). Fundamentos de enfermagem. Rio de Janeiro: Elsevier.

Ross, R., Shaw, K. D., Rissanen, J., Martel, Y., de Guise, J., \& Avruch, L. (1994). Sex differences in lean and adipose tissue distribution by magnetic resonance imaging: anthropometric relationships. The American Journal of Clinical Nutrition, 59(6), 1277-1285.

Sanches, I. J., Gamba, H. R., Souza, M. A. de, Neves, E. B., \& Nohama, P. (2013). 3D image fusion using MRI/CT and infrared images. Revista Brasileira de Engenharia Biomédica, 29(3), 298-308.

http://doi.org/10.4322/rbeb.2013.031

Savastano, D. M., Gorbach, A. M., Eden, H. S., Brady, S. M., Reynolds, J. C., \& Yanovski, J. A. (2009). Adiposity and human regional body temperature. The American Journal of Clinical Nutrition, 90(5), 1124-1131. http://doi.org/10.3945/ajcn.2009.27567 